\title{
Profile of mRNA Expression of Ki-67 in Breast Cancer Patients Pre- and Post- Chemotherapy
}

\author{
Prihantono Prihantono ${ }^{1}$, Daniel Sampepajung ${ }^{1}$, Andi Asadul Islam ${ }^{1}$, Mochammad Hatta ${ }^{2,}$, \\ Warsinggih Rahardjo ${ }^{1}$, Christian Binekada ${ }^{3}$, Eddy Herman Tanggo ${ }^{4}$ \\ ${ }^{1}$ Department of Surgery, Faculty of Medicine, Hasanuddin University, Makassar, Indonesia \\ ${ }^{2}$ Molecular Biology and Immunology Laboratory, Faculty of Medicine, Hasanuddin University, Makassar, Indonesia \\ ${ }^{3}$ Department of Surgery, Faculty of Medicine, Haluoleo University, Kendari, Indonesia \\ ${ }^{4}$ Department of Surgery, Faculty of Medicine, Airlangga University, Surabaya, Indonesia
}

Email address:

hattaram@indosat.net.id (M. Hatta)

${ }^{*}$ Corresponding author

\section{To cite this article:}

Prihantono Prihantono, Daniel Sampepajung, Andi Asadul Islam, Mochammad Hatta, Warsinggih Rahardjo, Christian Binekada, Eddy Herman Tanggo. Profile of mRNA Expression of Ki-67 in Breast Cancer Patients Pre- and Post- Chemotherapy. American Journal of Clinical and Experimental Medicine. Vol. 5, No. 1, 2017, pp. 10-14. doi: 10.11648/j.ajcem.20170501.13

Received: December 7, 2016; Accepted: December 20, 2016; Published: January 19, 2017

\begin{abstract}
Background: Proliferation is a distinct hallmarks of cancer. Ki-67 designated as a marker of proliferation in solid tumors. The proliferative activity of tumor demonstrated by expression of Ki-67 in breast cancer has been associated with a poor prognosis. Changes in the relative proportions of Ki-67 can be observed during chemotherapy and may correlated with clinical response in breast cancer. Purpose: Evaluate changes in mRNA expression of proliferation marker Ki-67 in breast cancer patients pre- and post-chemotherapy in relation with clinical response to chemotherapy. Method: This is a longitudinal study, 30 subjects breast cancer tissue samples pre- and post-chemotherapy using cyclophosphamide, adriamycin, 5FU regiment. We using qRT-PCR techniques to detect mRNA expression of Ki-67. Chemotherapy response is calculated using RECIST criteria. Results: Mean value of Ki-67 mRNA expression on breast cancer patients pre-chemotheraphy was 11.837 \pm 0.360 . Mean value of Ki-67 mRNA expression on breast cancer patients post-chemotheraphy was $11.241 \pm 1.971$. There was no significant correlation between expression of Ki-67 mRNA prechemotherapy with clinical response to chemotherapy, $p$ $=0.862(p \geq 0.05)$. There is a positive correlation between velocity of Ki-67 mRNA expression with clinical response with value of $\mathrm{r}=0.378$, this correlation was significant with $p=0.020(p<0.05)$. Conclusion: Chemotherapy cause decrease in mRNA expression of Ki-67. There is insignificant correlation between expression of mRNA Ki-67 baseline with chemotherapy response. Velocity of Ki-67 mRNA expression has significant correlation with clinical response to chemotherapy.
\end{abstract}

Keywords: Breast Cancer, Chemotherapy, mRNA, Ki-67, QRT-PCR

\section{Introduction}

Proliferation has been recognized as a distinct hallmark of cancer [1]. $\mathrm{Ki}-67$ is a core protein that is expressed on the cell being proliferated and the level of expression changes throughout the cell cycle [2]. Ki-67 is expressed below 3\% in healthy breast tissue. Ki-67 proliferation index has prognostic and predictive benefit in breast cancer [3]. Several studies have found changes in the expression of Ki-67 pre- and postchemotherapy become a strong and independent predictor of the disease-free period and survival. This is the reason that the tumor response in many neoadjuvant chemotherapy trials are now evaluated by examination of $\mathrm{Ki}-67$ in immunohistochemistry [4]. The problem of using immunohistochemistry for Ki-67 is the lack of consensus on the cut-off value of Ki-67 for the administration of chemotherapy and there seems to be a gray zone [5]. Some Studies reveal that mRNA expression of Ki-67 seems to be more robust and meaningful than the determination based on the Ki-67 protein by immunohistochemistry, either by visual scoring or quantitative image analysis [6]. The aim of this study was to evaluate mRNA expression of Ki-67 pre- and 
post-chemotherapy in associations with breast cancer chemotheraphy response.

\section{Materials and Method}

\subsection{Collection of Samples}

Study was conducted within a population of breast cancer patients who had been diagnosed through clinical and histopathology examination, which entered the Wahidin Sudirohusodo Hospital in Makassar, South Sulawesi, Indonesia. Inclusion criteria were female patients with locally advanced breast cancer and histopathological type of invasive ductal carcinoma. Exclusion criteria was inadequate tissue samples and patient had been undergoing chemotherapy, targeting therapy or hormonal therapy.

All samples who fulfilled inclusion and exclusion criteria and willing to participate in the study and signing informed consent. The samples consisted of 30 patients with breast cancer who have undergone combinations chemotherapy of cyclophosphamide, adriamycin and 5FU manufactured by Kalbe Farma Indonesia. Chemotherapy was prescribed by official doctors.

\subsection{Immunohistochemistry Examination}

Evaluation of estrogen and progesterone receptors (ER, PR) and HER2 expression by immunohistochemistry are routinely performed in breast carcinomas in our hospitals. Immunohistochemistry was performed, following epitope retrieval, with a polymer based detection system (Envision plus, Dako, Carpinteria, CA) using mouse monoclonal antibodies for ER and PR (Dako, Carpinteria, CA), ER (1D5; 1:50), PR (PgR636; 1:400), and Herceptin kit (HercepTest, Dako, Carpinteria, CA) according to the manufacturer's instructions [7].

\subsection{Nucleic Acid Isolation}

Nucleic acid was extracted from breast cancer tissue according to the diatom guanidinium isothiocyanate (GuSCN) method described by Boom et al. 1990. Breast cancer tissue was mixed with $500 \mu$ of lysis buffer L6 (50mMTris- $\mathrm{HCl}, 5.25 \mathrm{M}$ GuSCN, 20mM EDTA, 0.1\% Triton $\mathrm{X} 100$ ), vortexes vigorously, and centrifuged at $1,000 \mathrm{rpm}$ for $5 \mathrm{~min}$. To obtain the nucleic acid, samples were lysed by incubation for 15 minutes at $18^{\circ} \mathrm{C}$ and $20 \mu \mathrm{l}$ of diatom suspension was added. The diatom containing the bound nucleic acid was centrifuged at $12,000 \mathrm{x}$ g for 15 seconds to obtain diatom pellet. The diatom pellet was then washed with washing buffer $\mathrm{L} 2(5.25 \mathrm{M} \mathrm{GuSCN}$ in $0.1 \mathrm{M}$ Tris- $\mathrm{HCl}$, pH6.4), rinsed with 70\% ethanol and acetone, and dried by incubation at $56^{\circ} \mathrm{C}$ for 10 minutes. The pellet was mixed with $60 \mu \mathrm{l}$ of $10 \mathrm{mM}$ Tris- $\mathrm{HCl}, \mathrm{pH} 8.0,1 \mathrm{mM}$ EDTA buffer and the nucleic acid was eluted by incubation at $56^{\circ} \mathrm{C}$ for 10 minutes. After sedimentation of the diatom by centrifugation, the supernatant was collected and stored at $-20^{\circ} \mathrm{C}$ until RealTime PCR was performed [8].

\subsection{Expression mRNA Ki-67 Genes by Real Time PCR}

Detection of mRNA expression of Ki-67 was done according to Real time PCR method previously describe by Mitas, 2001 and Potemski, 2006. Specific primers for mRNA Ki-67 were used: Ki-67 forward: TCCTTTGGTGGGCA CCTAAGACCTG and Ki-67 reverse: TGATGGTTGAG GTCGTTCCTTGATG. Cycle RT PCR for Ki-67 was $94^{\circ} \mathrm{C}$ for 3 minute; $94^{\circ} \mathrm{C}$ for 30 second 38 cycles and next step is PCR: $51^{\circ} \mathrm{C}$ for 30 second. Also, specific primers of housekeeping genes were used GAPDH forward: TGAGT GCTGTCTCCATGTTTGA and GAPDH reverse: TCTGC TCCCCACCTCTAAGTTG. [9, 10]

\subsection{Data Analysis}

Data analysis using the SPSS (Statistical Package for Social Science) version 22. Normality of the samples were analyzed using shapiro wilk's test. Analysis of patient's characteristics and clinical response using chi square. Analysis of mean difference of Ki-67 mRNA expression between responsive and nonresponsive groups used wilcoxon test, to see the correlation using the pearson and spearman test.

\subsection{Ethical Clearence}

Ethical approval for this study was obtained from Research Ethics Committee, Faculty of Medicine, Hasanuddin University, Makassar, Indonesia.

\section{Results}

During the period from July 2015 to August 2016 acquired research subjects were 30 patients with breast cancer which meet the inclusion criteria. Minimum age of subject was 28 years and maximum was 64 years old, the mean age of subjects in this research was 50.3 years. Analysis of the age factor to clinical response to chemotherapy between age $\leq 50$ years and $>50$ years, statistically no significant with $p=0.581$ ( $>0.05$ ). Histopathologic grading obtained Low grade 2 cases $(6.7 \%)$, Moderate grade 19 cases $(63.3 \%)$ and High grade $9(30 \%)$. Analysis of the grade factor to clinical response to chemotherapy between low, moderate and high grade, no significant statistically with $p=0.408 \quad(p>0,05)$. Immunohistochemistry examination panel obtained subtypes luminal 16/30 (56.6\%), Her2 8/30 (26.6\%) and triple negative $6 / 30(20 \%)$. Analysis of the Imunohistochemistry profile with clinical response to chemotherapy, no significant statistically with ER $p=0.060 \quad(p>0,05), \quad$ PR $p=0.515$ $(p>0,05)$, Her2 $p=0.340(p>0,05)$. The clinical response to neoadjuvant chemotherapy; responsive as much as $23 / 30$ (76.7\%) and nonresponsive 7/30 (23.3\%).

Table 1. Patients characteristic.

\begin{tabular}{ll}
\hline Characteristic & n (\%) \\
\hline Age & \\
$\leq 50$ & $14(46,7 \%)$ \\
$>50$ & $16(53,3 \%)$ \\
\hline
\end{tabular}




\begin{tabular}{ll}
\hline Characteristic & n (\%) \\
\hline Grade & \\
Low Grade & $2(6,7 \%)$ \\
Moderate Grade & $19(63,3 \%)$ \\
High Grade & $9(30 \%)$ \\
Immunohistochemistry & \\
ER & $8(26,7 \%)$ \\
PR & $11(36,6 \%)$ \\
HER2 & $17(56,6 \%)$ \\
Clinical response & \\
Responsive & $23(76,7 \%)$ \\
Nonresponsive & $(23,3 \%)$ \\
\hline
\end{tabular}

Mean value of Ki-67 mRNA on breast cancer patients prechemotheraphy which responsive to chemotherapy was
$11.830 \pm 0.334$ whereas on nonresponsive was $11.858 \pm 0.466$. Mean value of Ki-67 mRNA on breast cancer patients post chemotheraphy which responsive to chemotherapy was $10.862 \pm 1.965$, whereas on nonresponsive was $12.487 \pm 1.501$. In the responsive group expression of $\mathrm{Ki}-67 \mathrm{mRNA}$ tend to decreased by 0.97 . In the group nonresponsive expression of Ki-67 mRNA likely to increase by 0.63 . There was no significant correlation between expression of Ki-67 mRNA prechemotherapy with clinical response to chemotherapy, $p=$ $0.862(p \geq 0.05)$. There was no significant correlation between expression of Ki-67 mRNA postchemotherapy with clinical response to chemotherapy, $p=0.054(p \geq 0.05)$.

Table 2. Comparison expression of $m R N A$ Ki-67 pre-and post-chemotherapy with clinical response.

\begin{tabular}{llll}
\hline mRNA Expression & Responsive $(\mathbf{n}=\mathbf{2 3})$ & Non Responsive $(\mathbf{n}=\mathbf{7})$ & Mean difference $^{*}$ \\
\hline Ki-67 (Prechemoterapy) & $11.83 \pm 0.33$ & $11.85 \pm 0.46$ & 0.02 \\
Ki-67 (Postchemoterapy) & $10.86 \pm 1.96$ & $12.48 \pm 1.50$ & 1.62 \\
Mean difference & 0.97 & -0.63 & 0.862 \\
\hline
\end{tabular}

$\mathrm{p}=*$ Wilcoxon test

Table 3. Correlations expression of $m R N A$ Ki-67 pre- and post-chemotherapy, velocity of $m R N A$ Ki-67 and chemotherapy response.

\begin{tabular}{|c|c|c|c|}
\hline & $m R N A$ Expression (Mean \pm SD) & Correlation with Chemotherapy response (r) & $p$ \\
\hline mRNA Ki-67 (prechemotherapy) & $11.837 \pm 0.360$ & 0.028 & $0.885 *$ \\
\hline mRNA Ki-67 (Postchemotherapy) & $11.241 \pm 1.971$ & -0.368 & $0.046 * *$ \\
\hline Velocity mRNA Ki-67 & $5.021 \pm 16.438$ & 0.378 & $0.039 * *$ \\
\hline
\end{tabular}

$\mathrm{p}=*$ pearson $* *$ spearman

There is a positive correlation between mRNA expression of Ki-67 prechemotherapy with clinical response with value of $\mathrm{r}=0.028$, this correlation was insignificant with $p=0.885$ $(p>0.05)$. There is a negative correlation between mRNA expression of Ki-67 postchemotherapy with clinical response with value of $\mathrm{r}=-0.368$, this correlation was significant with $p=0.046(p<0.05)$. There is a positive correlation between velocity of Ki-67 mRNA expression with clinical response with value of $\mathrm{r}=0.378$, this correlation was significant with $p=0.039(p<0.05)$.

\section{Discussion}

In this research, the analysis of the age, grade and immunohistochemistry profiles with clinical response, found no significant relationship. Previous research found no relationship between age and pathological complete response $[11,12]$. Some studies found grade does not relate to the numbers of pathological complete response, but significantly associated with disease free survival and overall survival of breast cancer patients receiving chemotherapy [11, 13]. Studies found poor response of anthracycline chemotherapy in immunohistochemistry of ER and PR positive. [14, 15] Previous studies found Her2 positive as predictor of anthracycline chemotherapy response [16, 17]

Protein Ki-67 is a convenient and reproducible marker for solid cancer proliferation [1, 18]. Some literature mentions that the expression levels of $\mathrm{Ki}-67$ were associated with poor prognosis [19]. St Gallen Consensus has recommended the use of the proliferation marker $\mathrm{Ki}-67$, in determining optimal treatment strategies for early stage breast cancer [20]. Research has shown that the Ki-67 overexpression correlated with disease free survival and overall survival [21]. Tumors that have high levels of proliferation is have a better response to chemotherapy. However, in the multivariable analysis, not all studies show that baseline Ki-67 can be a predictor of pathological complete response. [22] Ki-67 themselves are not shown to predict the benefit of chemotherapy adjuvant cyclophosphamide, methotrexate and fluorouracil [23]. Baseline Ki-67 reported trend incremental benefits of taxane to anthracycline-based chemotherapy in high Ki-67 compared lower Ki-67 cancer that warrants further investigation [24].

Tumors with Ki-67 mRNA expression were examined by qRT-PCR is associated with disease free survival and overall survival of patients treated with adjuvant chemotherapy regimen. The results showed that the tumor with Ki-67 mRNA expression may be valuable for election patients for adjuvant therapy containing docetaxel [25].

Several studies have found changes in the expression of Ki-67 pre- and post-chemotherapy become a strong and independent predictor of the disease-free period and survival. This is the reason that the tumor response in many neoadjuvant chemotherapy trials are now evaluated by examination of Ki-67 in immunohistochemistry [4].

Studies found that the mRNA expression of Ki-67 was associated with a higher high pathological complete response rate of $36.4 \%$ compared with $5.8 \%$ in tumors with $\mathrm{Ki}-67$ mRNA levels are low. mRNA expression of Ki-67 were measured by qRT-PCR is predictive for the achievement of 
pathological complete response for neoadjuvant chemotherapy and is superior to the $\mathrm{Ki}-67$ expression was determined with immunohistochemistry [6]. qRT-PCR-based measurement of Ki-67 mRNA ensure an objective and highly reproducible quantification of proliferation activity of formalin-fixed paraffin-embedded (FFPE) tissue biopsy core of routine cut. Because it seems to be more robust and meaningful than the determination based on the Ki-67 protein by immunohistochemistry, either by visual scoring or quantitative image analysis. [6]

\section{Conclusion}

Chemotherapy cause decrease in mRNA expression of $\mathrm{Ki}$ 67. There is insignificant correlation between expression of mRNA Ki-67 baseline with chemotherapy response. There is significant correlation between expression of mRNA Ki-67 postchemotherapy with chemotherapy response. Consistently shown that the Ki-67 mRNA expression in the responsive group tended to decrease, whereas the mRNA expression of $\mathrm{Ki}-67$ in the group that nonresponsive tends to increase. Velocity of Ki-67 mRNA expression has significant correlation with clinical response to chemotherapy.

\section{References}

[1] Hanahan D, Weinberg RA. Hallmarks of cancer: the next generation. cell. 2011;144 (5): 646-74.

[2] Scholzen T, Gerdes J. The $\mathrm{Ki}-67$ protein: from the known and the unknown. Journal of cellular physiology. 2000;182 (3): $311-22$.

[3] Van Diest P, Van Der Wall E, Baak J. Prognostic value of proliferation in invasive breast cancer: a review. Journal of clinical pathology. 2004;57 (7): 675-81.

[4] Jones RL, Salter J, A'Hern R, Nerurkar A, Parton M, ReisFilho JS, et al. The prognostic significance of Ki67 before and after neoadjuvant chemotherapy in breast cancer. Breast cancer research and treatment. 2009;116 (1): 53-68.

[5] Goldhirsch A, Winer EP, Coates A, Gelber R, Piccart-Gebhart M, Thürlimann B, et al. Personalizing the treatment of women with early breast cancer: highlights of the St Gallen International Expert Consensus on the Primary Therapy of Early Breast Cancer 2013. Annals of oncology. 2013; 24 (9): 2206-23.

[6] Marme F, Schneeweiss A, Aigner J, Eidt S, Altevogt P, Sinn P, et al. Abstract P3-06-08: Ki-67 mRNA as a predictor for response to neoadjuvant chemotherapy in primary breast cancer. Cancer Research. 2012;72(24 Supplement): P3-06-8P3--8.

[7] Williams SL, Birdsong GG, Cohen C, Siddiqui MT. Immunohistochemical detection of estrogen and progesterone receptor and HER2 expression in breast carcinomas: comparison of cell block and tissue block preparations. Int J Clin Exp Pathol. 2009; 2 (5): 476-80.

[8] Boom R, Sol C, Salimans M, Jansen C, Wertheim-van Dillen $P$, Van der Noordaa J. Rapid and simple method for purification of nucleic acids. Journal of clinical microbiology.
1990; 28 (3): 495-503.

[9] Mitas M, Mikhitarian K, Walters C, Baron PL, Elliott BM, Brothers TE, et al. Quantitative real-time RT-PCR detection of breast cancer micrometastasis using a multigene marker panel. International journal of cancer. 2001; 93 (2): 162-71.

[10] Potemski P, Pluciennik E, Bednarek AK, Kusinska R, Kubiak $\mathrm{R}$, Jesionek-Kupnicka $\mathrm{D}$, et al. Ki-67 expression in operable breast cancer: a comparative study of immunostaining and a real-time RT-PCR assay. Pathology-Research and Practice. 2006; 202 (7): 491-5.

[11] Luangdilok S, Samarnthai N, Korphaisarn K. Association between pathological complete response and outcome following neoadjuvant chemotherapy in locally advanced breast cancer patients. Journal of breast cancer. 2014; 17 (4): 376-85.

[12] Rouzier R, Perou CM, Symmans WF, Ibrahim N, Cristofanilli $\mathrm{M}$, Anderson $\mathrm{K}$, et al. Breast cancer molecular subtypes respond differently to preoperative chemotherapy. Clinical Cancer Research. 2005;11 (16): 5678-85.

[13] Engstrøm MJ, Opdahl S, Hagen AI, Romundstad PR, Akslen LA, Haugen OA, et al. Molecular subtypes, histopathological grade and survival in a historic cohort of breast cancer patients. Breast cancer research and treatment. 2013; 140 (3): 463-73.

[14] Lønning PE. Poor-prognosis estrogen receptor-positive disease: present and future clinical solutions. Therapeutic advances in medical oncology. 2012: 1758834012439338.

[15] Colleoni M, Montagna E. Neoadjuvant therapy for ERpositive breast cancers. Annals of Oncology. 2012; 23(suppl 10): x243-x8.

[16] Zhang J, Liu Y. HER2 over-expression and response to different chemotherapy regimens in breast cancer. Journal of Zhejiang University Science B. 2008; 9 (1): 5-9.

[17] Hamy-Petit A-S, Belin L, Bonsang-Kitzis H, Paquet C, Pierga J-Y, Lerebours F, et al. Pathological complete response and prognosis after neoadjuvant chemotherapy for HER2-positive breast cancers before and after trastuzumab era: results from a real-life cohort. British journal of cancer. 2016; 114 (1): 4452.

[18] Dowsett M, Nielsen TO, A'Hern R, Bartlett J, Coombes RC, Cuzick J, et al. Assessment of Ki67 in breast cancer: recommendations from the International Ki67 in Breast Cancer working group. Journal of the National Cancer Institute. 2011.

[19] Luporsi E, André F, Spyratos F, Martin P-M, Jacquemier J, Penault-Llorca F, et al. Ki-67: level of evidence and methodological considerations for its role in the clinical management of breast cancer: analytical and critical review. Breast cancer research and treatment. 2012; 132 (3): 895-915.

[20] Denkert C, Sinn BV, Issa Y, Müller BM, Maisch A, Untch M, et al. Prediction of response to neoadjuvant chemotherapy: new biomarker approaches and concepts. Breast Care. 2011;6 (4): 265-72.

[21] Colozza M, Azambuja E, Cardoso F, Sotiriou C, Larsimont D, Piccart M. Proliferative markers as prognostic and predictive tools in early breast cancer: where are we now? Annals of oncology. 2005; 16 (11): 1723-39. 
[22] Yerushalmi R, Woods R, Ravdin PM, Hayes MM, Gelmon KA. Ki67 in breast cancer: prognostic and predictive potential. The lancet oncology. 2010; 11 (2): 174-83.

[23] Viale G, Regan MM, Mastropasqua MG, Maffini F, Maiorano E, Colleoni M, et al. Predictive value of tumor Ki-67 expression in two randomized trials of adjuvant chemoendocrine therapy for node-negative breast cancer. Journal of the National Cancer Institute. 2008; 100 (3): 207 12.
[24] Penault-Llorca F, André F, Sagan C, Lacroix-Triki M, Denoux $\mathrm{Y}$, Verriele V, et al. Ki67 expression and docetaxel efficacy in patients with estrogen receptor-positive breast cancer. Journal of Clinical Oncology. 2009;27 (17): 2809-15.

[25] Wirtz RM, Sihto H, Isola J, Heikkilä P, Kellokumpu-Lehtinen P-L, Auvinen P, et al. Biological subtyping of early breast cancer: a study comparing RT-qPCR with immunohistochemistry. Breast cancer research and treatment. 2016: 1-10. 